\title{
Virginia Tech sets policy on controversial materials
}

\author{
By Paul Metz and Bruce Obenhaus
}

\section{Make sure your library bas a written selection statement}

$\mathbf{L}$ ast year, a leader in the Virginia Tech gay student community offered to donate a year's subscription to The Advocate to the university libraries. He expressed the hope that the libraries would ultimately choose to subscribe on a paid basis.

The principal bibliographer's research indicated that The Advocate, the leading national magazine for the U.S. gay and lesbian community, had a circulation base of 250,000 and contained thoughtful analyses of issues of interest to a community whose emergence has been one of the outstanding features of recent social history. We also determined that despite this circulation base, there were only about 80 OCLC holdings for The Advocate. We construed this as a discouraging indication that many libraries were practicing self-censorship and deciding not to subscribe to a quality serial relevant to many of their patrons. For all these reasons, we gladly accepted the offer and have since converted to a paid subscription.

The decision to accept The Advocate raised our awareness of potential criticism of our collections and seemed to mark as good a time as any for our libraries to write a policy on the selection and treatment of controversial material. We did not really expect The Advocate to be challenged (nor has it been), but since any policy written in the midst of an active controversy will inevitably appear to be reactive and defensive, the very absence of controversy made it a good time for us to draft such a policy.

The recent publication of the fourth edition of the Intellectual Freedom Manual by ALA's
Office for Intellectual Freedom provides a standard by which we can now assess whether the policy we wrote is consistent with the philosophy of our professional association. To the extent that our policy does embody the principles endorsed by ALA, it may serve as a model, or at least a representative statement of some use to other libraries.

The full text of the Virginia Tech statement, which was approved by the University Library Committee and endorsed throughout the chain of the university governance structure, is reproduced in the accompanying sidebar. The following narrative attempts both to place our policy within the context of local history and practice at Virginia Tech and to compare the statement to the principles established by the ALA guidelines.

\section{Discussion of the policy}

The following comments are intended to provide local context or to elaborate on the policy as a possible embodiment of ALA's goals.

1) The most important aspect of the policy is its existence. As the Manual points out, "Collection development and the selection of materials should be done according to professional standards and established selection and review procedures." By supplementing Tech's existing collection development policy statement and more procedurally oriented Bibliographers' Manual, the statement guarantees that almost any selection decision will take place within a complete policy structure and can be assessed by reference to existing policies and procedures.

2) The policy does not rest on the libraries' ability to endorse the materials we collect. As the Manual states, "Libraries do not advocate the ideas found in their collections. The presence of a magazine or book in a library does 
not indicate an endorsement of its contents by the library."

Our policy's reference to pseudo-science is intended to disclaim endorsement by conveying our understanding that some of what we collect will be known to be false at the time by most relevant experts or will later be universally acknowledged as incorrect. Indeed, the only item we have been asked to remove in recent years was a pseudo-scientific technical paper whose author represented a religious sect (this request was denied at a lower administrative level and not appealed). We would consider our collections in science studies and social history incomplete without materials on Lamarckian interpretations of evolution, or indeed without creationist materials.

3) The policy puts our libraries' acquisition of erotic materials in a broad context of other materials not of direct relevance to our curriculum. It is not always easy, in the midst of controversy, to defend one's selection of erotic materials not directly related to the university's mission. The policy serves to remind our public of the breadth of our charge. On a practical level, the analogy of erotic materials to materials in Portuguese or on nursing (not taught at Tech) or even on more mundane topics such as chess, racquetball, or car repair may serve to defuse criticism.

4) The policy does not allow for the labelling or age-based segregation of materials. As the ALA Policy Manual states "Libraries cannot act in loco parentis. Nevertheless, ALA acknowledges and supports the exercise by parents of their responsibility to guide their own children's viewing. . ."

Anyone may use the general collections of the Virginia Tech Libraries. Use of reserve materials or materials in the media center, however, requires that a university ID or borrower's card be presented. Any adult living in Virginia, or any Virginia child whose parent signs a consent form representing the parent's ultimate li-

\section{The selection and treatment of erotic or other controversial materials in the university libraries}

The university libraries acquire each year a small percentage of the world's volume of publications. In selecting materials for inclusion in our collections, we attempt first to acquire those items that relate to university programs and hence will support the university's goals in research, instruction, and service.

Beyond this, we attempt to represent to some degree the entire span of humanity's cultural heritage. Disciplines and languages not taught at the university are represented selectively. The entire range of human cultural practice, of science and pseudo-science, and of religious, political, ethnic, and social expression is welcome in our collections insofar as representative materials may be acquired with scarce resources. To build our collections with any other goal in mind would be to ignore both the root and the deeper meaning of the term "university."

While we do not acquire materials purely for their prurient interest, our selection practices necessarily recognize that eroticism is often an integral part of many forms of cultural expression and that human sexuality is an important area of study for both the biological and social sciences.

Once any library materials have been acquired, our concern is to make them available to as many patrons as may want them. As educators in a democracy, we must have faith in our patrons to identify and select those materials most beneficial to their purposes. We are entirely in accord with the principles of intellectual freedom expressed in the American Library Association's "Library Bill of Rights" and supporting documents in Chapter 53 of the ALA Policy Manual, including the rejection of practices denying or restricting access to materials or labelling materials.

Common sense and our own practical experience have indicated that theft and mutilation of library materials dealing with sexuality is common. For this reason, we have chosen to place on Reserve some materials deemed to be at risk. Here they may be protected from theft and damage, along with a variety of other, nonerotic materials which have been found to be vulnerable to theft and mutilation. 


\section{Banned Books Week-Celebrating the freedom to read}

The 1993 observance of Banned Books Week will take place September 25 through October 2. Now in its 11th year, Banned Books Week calls attention to the dangers of censorship and encourages support for the freedom to read. Cosponsored by the American Library Association, the American Booksellers Association, the American Booksellers Foundation for Free Expression, the Association of American Publishers, the National Association of College Stores and the American Sociery of Journalists and Authors, and endorsed by the Library of Congress Center for the Book, Banned Books Week focuses national attention on the surprising pervasiveness of censorship in our society, and encourages discussion of First Amendment rights, free expression and access to information.

ability for fines and unreturned materials, is eligible for such a card. Our parental consent form has been modified to include that the libraries do not attempt to deny or restrict access to materials and that "guardians assume responsibility for the appropriateness and nature of materials minors check out."

\section{As educators in a democracy, we must have faith in our patrons to identify and select those materials most beneficial to their purposes.}

From a parent's perspective, the choices are fairly clear. A child's access to the general collection for in-house use can be prevented only by parental rule. Circulation privileges, access to reserve, and access to the media center come as a "package deal," and a parent signing a consent form gives permission for them all. It is not possible for a parent to restrict a child's access to only a specified set of materials.

5) The policy does not allow restricted access as a means of censorship. This is in keeping with section 2.9 of the Intellectual Free-
Each year, the American Library Association, with its cosponsors, publishes the Banned Books Week-Celebrating the Freedom to Read Resource Kit. The $\$ 25.00$ kit includes four posters, 100 bookmarks, and a Resource Book with annotated lists of books challenged or banned (reprints of the list are available separately), quotes on the First Amendment, ideas for activities and displays, camera-ready art, and sample press releases and public service announcements, all designed to convey a simple message: celebrate the freedom to read!

For further information about Banned Books Week and to order the Banned Books Week Resource Kit, contact the Office for Intellectual Freedom, American Library Association, 50 E. Huron Street, Chicago, IL 60611, (312) 5452433 ext. 4223.

dom Manual, which points to the potential embarrassment or inhibition patrons feel in having to ask for materials. Yet the policy attempts to reflect the common sense the Manual expresses in the same section, when it acknowledges that "There may be, however, countervailing factors to establish policies to protect library materials - specifically, for reasons of physical preservation including protection from theft or mutilation." 3

The Manual goes on to note that "Any such policies must be carefully formulated and administered with extreme attention to the principles of intellectual freedom." Prior to our policy of placing erotic materials on reserve, about 50 volumes of such materials had been held in special collections. They were very rarely used, reflecting no doubt patron reluctance to ask for them. To use materials on reserve, patrons need only submit a slip with the item's call number. Paradoxically, to ask for erotic materials in the high traffic, busy environment of reserve is a more private act than to ask as the sole patron visiting the sole attendant on duty in special collections.

We have tried not to be overly protective in decisions about where to place materials. The Advocate is shelved with other materials and

(continued on page 394) 
Struggling to survive in the face of severe federal funding cutbacks, more and more Native American tribes have turned to gambling to keep their reservations going. With some reservation casinos grossing millions of dollars a year, the plan has seemed successful. But some state legislators

\section{In their latest fight With the government, Native Americans HAVE RESORTED TO SOME POWERFUL NEW WEAPONS.}

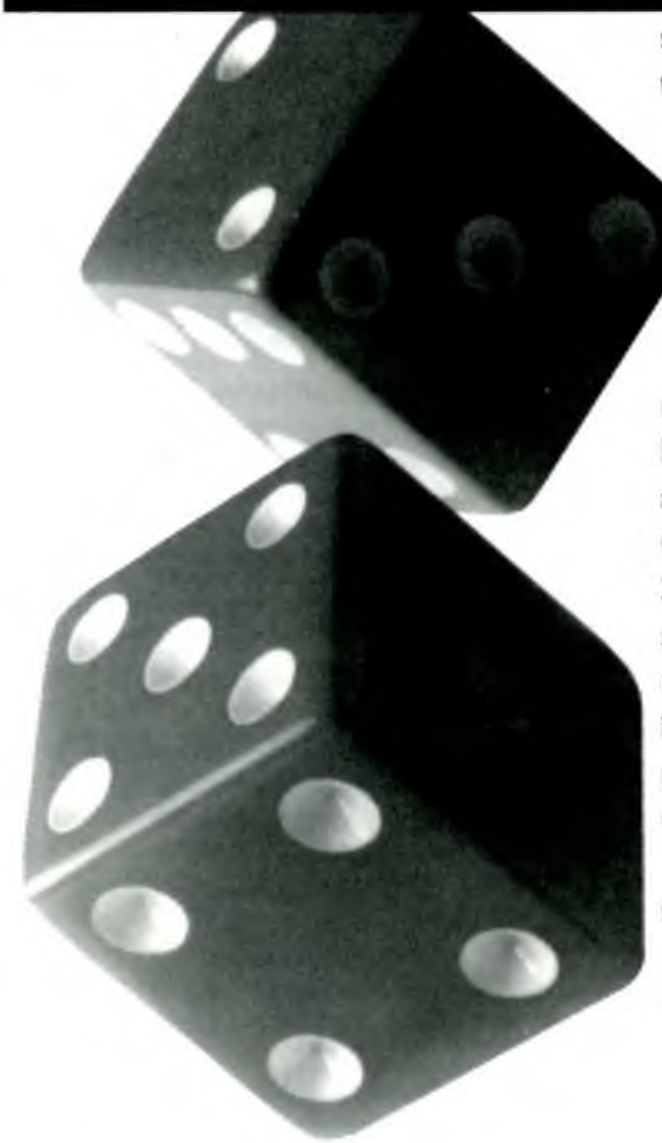

say it's bad medicine. And so the conflict between the cowboys and the Indians continues...

Legislation on Native American casinos is an issue that packs significant national import. Which is why it's one of the thousands of subjects covered by PAIS International.

\section{Coverage that crosses all borders}

From Congressional legislation to banking regulations, PAIS International provides a unique breadth of coverage on state, interstate, national and international levels. In all, PAIS online and CD-ROM indexes give you access to over 350,000 journal articles, government documents, statistical directories, monographs, conference reports and more. And to provide an unrivaled international outlook, PAIS references literature published around the world in English, French, German, Italian, Spanish and Portuguese.

So the next time you're shooting for hard-tofind data, don't gamble. Use PAIS.

Public Affairs Information Service," Inc.

521 West 43rd Street, New York, NY 10036-4396 800-288-PAIS, 212-736-6629 (in NYC) Fox: 212-643-2848

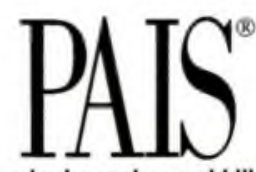

No one looks at the world like PAIS

In Print: PAIS INTERNATIONAL IN PRINT * PAIS SUBJECT HEADINGS Online Through: DATA.STAR • DIALOG • OCLC • RLG On CD-ROM: PAIS ON CD-ROM - PAIS INTERNATIONAL ON SILVERPLATTER On Magnetic Tape: CONTACT PAIS FOR INFORMATION 


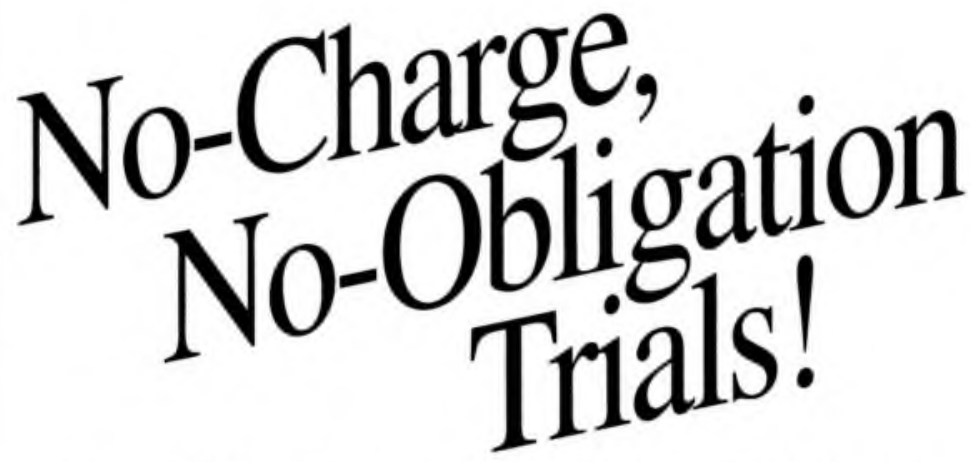

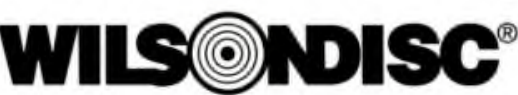

CD-ROM Retrieval System

Three search modes, no-charge online search. ing, as well as generous networking and remote access policies make WILSONDISC the most library-friendly CD-ROM retrieval system available. Sign up today for a 90-day trial.
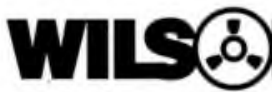

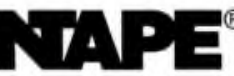

Database Licensing Service

By mounting the Wilson databases on in-house computer systems, you make the data accessible with the same hardware and software used for the public access catalog or other locally-loaded databases. Sign up today for a one-year trial.

\section{Databases Available}

- Applied Science \& Technology Index

- Art Index

- Biography Index

- Biological \& Agricultural Index

- Book Review Digest

- Business Periodicals Index

- Cumulative Book Index

- Education Index

- Essay and General Literature Index

- General Science Index

- Humanities Index

- Index to Legal Periodicals

- Library Literature
- MLA International Bibliography *+

- Readers' Guide Abstracts

- Readers' Guide Abstracts Select Edition *

- Readers' Guide to Periodical Literature

- Sears List of Subject Headings **

- Social Sciences Index

- Wilson Business Abstracts

;WILSONDISC OnIY " "WILSONTAPEONIY

1 Published by the Modern Language Association

Call Toll-Free 800-367-6770

T II I II, H, WI I S O N C O M P A KYY

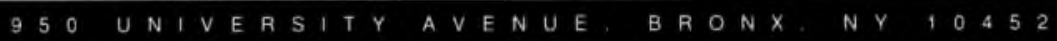


It was very hard for the library staff to sit in the closet when they wanted to burst into the room to correct the erroneous information.

\section{Conclusion}

Focus groups, if conducted properly using the 12 steps presented, can provide a wealth of information. They are a good method for determining what issues and concerns should be addressed in follow-up quantitative research. Remember that focus groups are only one part of the research process.

\section{References}

Baker, Sharon L. "Improving Business Services Through the Use of Focus Groups." $R Q 30$ (Spring 1991) 377-385.

Hayes, Thomas J., and Carol B. Tathum (eds.). Focus Group Interviews: A Reader. Chi- cago: American Marketing Assoc., 1989.

Merton, Robert K., Marjorie Fiske, and Patricia L. Kendall. The Focused Interview: $A$ Manual of Problems and Procedures. New York: Free Press, 1990.

Morgan, David L. Focus Groups as Qualitative Research. Newbury Park, Calif: Sage Publications, 1988.

Stewart, David W., and Prem N. Shamdasani. Focus Groups: Theory and Practice. Newbury Park, Calif: Sage Publications, 1990.

Templeton, Jane Farley. Focus Groups: $A$ Guide for Marketing and Advertising Professionals. Chicago: Probus Publishing Co., 1987.

Widdows, Richard, Tia A. Hensler, and Marlaya H. Wyncolt. "The Focus Group Interview: A Method for Assessing Users' Evaluation of Library Service." College and Research Libraries 52 (July 1991) 353-359.
(Controversial materials cont. from page 388)

shows a high incidence of theft and mutilation. Many books like A Secret Garden or The Story of $O$ have been bought for the general collection, but replacement copies have been sent to reserve after experience has shown we cannot keep them safe in the stacks. For certain other materials, such as The Joy of Lesbian Sex, it seems foolish not to assume that the probability of theft is so high that we should not put the first copy on reserve and be done with it.

The general philosophy we have come to is that pragmatism can go a long way to defuse or deflect issues that are often injected with an overload of symbolic significance. Much as the identification of erotic materials with books on racquetball or chess serves to defuse a potentially controversial collection development issue, the location of highly sensitive materials on reserve is made less questionable by their sharing this designation with Billboard, Rolling Stone, and the used car price guides, which we have also determined cannot be kept secure in the general collection.

6) In retrospect, and in light of the thoughtful discussion available in the Intellectual Freedom Manual, our policy probably over-emphasizes erotic materials and should place more stress on matters of religious belief or political ideology. If we were to rewrite the policy and to see it through the twists and turns of the governance process, we would include a greater defense of diversity in collections. ALA's careful delineation of diversity as a goal, (in con- trast to the more cautious, yet inevitably more controversial goal of "balance") as laid out in section 2.6 of the Intellectual Freedom Manual, should be reflected in any future iteration of our policy. ${ }^{+}$

\section{Notes}

${ }^{1}$ Office for Intellectual Freedom of the American Library Association, Intellectual Freedom Manual fourth edition (Chicago: ALA, 1992), p. 39.

${ }^{2}$ American Library Association, ALA Policy Manual, pp. 136-159 of ALA Handbook of Onganization 1991/92 (Chicago: ALA, 1991), p. 153.

"Intellectual Freedom Manual, p. 66.

"Diversity in Collection Development," in Intellectual Freedom Manual, pp. 49-57.

\section{Share your library's news}

CERL News wants to hear about your library's activities. Information in the News from the Field, Grants \& Acquisitions, and People in the News columns is gathered from press releases and notices we receive. If you don't share your ideas and activities with us we can't share them with CERL News readers. Be sure to put CERL News on your mailing list today. Send notices to the Editor, CERL News, 50 E. Huron St., Chicago, IL 60611; or e-mail: U38398@uicvm.uic.edu. 